\author{
Małgorzata Zakłos-Szyda, Nina Pawlik \\ Lodz University of Technology, Faculty of Biotechnology and Food Sciences, Institute of Technical \\ Biochemistry \\ Stefanowskiego 4/10, 90-924 Lodz, Poland, nina.pawlik@edu.p.lodz.pl
}

\title{
THE INFLUENCE OF VIBURNUM OPULUS POLYPHENOLIC COMPOUNDS ON METABOLIC ACTIVITY AND MIGRATION OF HELA AND MCF CELLS
}

\begin{abstract}
In recent years, research of antitumor activity of natural compounds isolated from plant material has increased. Polyphenols have gained significant attention due to their proapoptotic abilities and their involvement in migration and inhibition of metastasis processes. The anticancer effects of polyphenolic extracts of Viburnum opulus fruit against human breast (MCF-7) and cervical (HeLa) cancer cell lines have been confirmed in this study. It was demonstrated that the tested preparations (methanol - $M$ and acetone - A from pomace, juice - $J$ and juice after extraction to the solid phase SPE - PF) show cytotoxic activity and regulate the migration process of cancer cells. The degree of inhibition of cell migration was measured at two times - $24 \mathrm{~h}$ and $48 \mathrm{~h}$ after addition of the tested preparations. The highest toxicity towards both cell lines was demonstrated by the polyphenol fraction obtained after juice purification SPE $\left(I_{50}\right.$ values at concentration of 63,541 and $19,380 \mu \mathrm{g} / \mathrm{mL}$ for HeLa and MCF cell lines, respectively). At the same time, the same preparation inhibited cell migration the most (nearly $70 \%$ compared to controls at both times at the concertation of 15 and $30 \mu \mathrm{g} / \mathrm{mL}$ ). All preparations showed the antioxidant ability, but the Viburnum opulus juice (200 and $350 \mu \mathrm{g} / \mathrm{mL}$ ) and the preparation after its purification $(15$ and $30 \mu \mathrm{g} / \mathrm{mL})$ have larger ability to inhibit the intracellular oxidative stress $(30-40 \%)$ than preparation obtained from pomace (nearly by $20 \%$ at concentration of 20 and $50 \mu \mathrm{g} / \mathrm{mL}$ of $\mathrm{M}$ and A). Despite the antioxidative capacity of the preparations, they simultaneously decreased cellular mitochondrial potential. The results obtained indicate the high potential of components of Viburnum opulus polyphenolic compounds can be used in the production of innovative dietary supplements or pharmacological preparations for people with an increased risk or inclination towards developing breast or cervical cancer.
\end{abstract}

\section{Key words}

Viburnum opulus, polyphenols, cancer cells migration, mitochondrial potential, anti-oxidant effect.

\section{Introduction}

Despite significant advances in medical technology cancer remains one of the most aggressive and debilitating diseases worldwide. Surgery, chemotherapy and radiotherapy are commonly used for cancer treatment, however due to the harmful and painful side effects of these treatments, patients usually do not cope well with them [1]. Recently, much attention has been paid to the identification of natural chemopreventive substances capable of inhibiting, delaying or reversing the process of multistage carcinogenesis. Most of these naturally occurring phytocompounds retain antioxidant and anti-inflammatory properties that seem to contribute to their chemoprevention. Antioxidants, such as vitamins and polyphenols, include many compounds that can capture reactive oxygen species. Therefore, it has been proposed that antioxidants have potential benefits for the prevention and treatment of diseases associated with increased generation of reactive oxygen species and can be effective in reduction of carcinogenesis [2].

Viburnum opulus belongs to the Adoxaceae plant family, which can be found in eastern, north-eastern, western and central Europe and Turkey. The fruits are quite small, have a red color and are very acidic. They contain a large amount of polyphenols, as well as ascorbic acid and L-malic acid. According to several authors, Viburnum opulus juice is a source of flavonoids that contain $(+)-$ catechin, $(-)$ - epicatechin and quercetin glycosides. The juice also contains a large amount of chlorogenic acid (54\% of the total phenolic compound) and carotenoids, coleoic acid, epigallocatechin gallate, and quercetin [3, 4]. Due to the presence of these ingredients, it has a strong antioxidant effect and can be used in treatment of certain diseases, such as menstrual cramps, disorders of the nervous system as well as liver and biliary disorders. Recent studies have 
shown that it has a high antimicrobial potential and antioxidant activity, which are considered effective in reduction of risk of cancer[2].

Global data indicates that Western European countries have the highest rate of incidence of breast and cervical cancer. For many years researchers have been trying to identify the risk factors and to develop effective methods for their prevention and treatment [5]. Due to these reports we decided to investigate the effects of polyphenolic extracts obtained from Viburnum opulus fruits as anti-tumor agents able to counteract metastases. As cellular models, HeLa and MCF-7 cell lines were chosen. Furthermore, we focused on determining the antioxidative capacity of preparations of such polyphenolic extracts and their impact on potential cellular mitochondrial regulation. The research aimed to determine the usefulness of Viburnum opulus fruits in the development of preparations and dietary supplements dedicated for people with an increased risk of breast and cervical cancer with a tendency to metastasis.

\section{Materials and methods}

In order to obtain polyphenol extracts, the fruits of Viburnum opulus were homogenized and then centrifuged at $5000 \mathrm{rpm}$ for $10 \mathrm{~min}$ at $16^{\circ} \mathrm{C}$. The obtained juice was divided into a fraction enriched with polyphenols by solid phase extraction (SPE) on a Waters Sep-Pak ${ }^{\circledR} \mathrm{C}_{18} 35 \mathrm{cc}$ Vac (10 g sorbent per cartridge) under pressure. The enriched polyphenol fraction was eluted with methanol at a volume equal to twice the bed volume. The pulp was further extracted with methanol: acetone: water $(2: 2: 1 \mathrm{v} / \mathrm{v} / \mathrm{v})$ in a ratio of 1:10 w/v on the stirrer at $800 \mathrm{rpm}$ for $30 \mathrm{~min}$ and then centrifuged at $5000 \mathrm{rpm}$ for $10 \mathrm{~min}$ at $16^{\circ} \mathrm{C}$. The residue was back-extracted with a $70 \%$ acetone solution in a ratio of $1: 10 \mathrm{w} / \mathrm{v}$ and again centrifuged. The extracts obtained - polyphenols enriched, methanol and acetone - were concentrated at $40^{\circ} \mathrm{C}$ in a vacuum rotary evaporator (Büchi, Switzerland) and lyophilized.

The content of the total polyphenols was determined by using the Folin-Ciocalteu method. In a 96-well plate 10 $\mu \mathrm{L}$ of extract or water (control) was mixed with $40 \mu \mathrm{L}$ of 10-times diluted Folin-Ciocalteu reagent. The reaction was initiated by adding $20 \mu \mathrm{L}$ of $20 \%(w / w) ~ N a 2 C O 3$. The volume of reaction mixture was adjusted to $200 \mu \mathrm{L}$ with distilled water. After incubation at room temperature for 20 min the absorbance was measured at $760 \mathrm{~nm}$ (Synergy ${ }^{\text {TM }}$ 2, BioTek Instruments Inc.). Total polyphenols content was expressed as $\mathrm{mg}$ of gallic acid equivalent (GAE) per g of lyophilized material.

For biological activity assays, centrifuged juice $(\mathrm{J})$ and preparations of polyphenol fraction (PF), methanol (M) and acetone (A) extracts dissolved in a 50\% DMSO solution were used. Samples were stored at $-20^{\circ} \mathrm{C}$ before usage.

All cell culture reagents were obtained from Life Technologies (Carlsbad, USA). Human cervix adenocarcinoma HeLa cell line and human breast adenocarcinoma MCF-7 cell line were purchased from the American Type Cell Collection (ATCC). Cells were maintained at $37^{\circ} \mathrm{C}$ in a humidified incubator containing $5 \% \mathrm{CO}_{2}$ and $95 \%$ air. They were grown in DMEM medium with $10 \%$ fetal bovine serum (FBS), $100 \mu \mathrm{g} / \mathrm{mL}$ ampicillin, $100 \mu \mathrm{g} / \mathrm{mL}$ streptomycin and $100 \mathrm{IU} / \mathrm{mL}$ penicillin.

To determine the maximum non-toxic concentration and the $\mathrm{IC}_{50}$ dose, cells were seeded into 96-well plates at $10^{4}$ cells per well in complete medium and grown for $20 \mathrm{~h}$, then incubated in the presence of the extract diluted in DMSO and culture medium for $24 \mathrm{~h}$. Following incubation, $10 \mu \mathrm{l}$ of PrestoBlue cell viability reagent (Life Technologies, Van Allen Way, CA, USA), a resazurin-based solution, was added into each well and incubated further for $30 \mathrm{~min}$ at $37^{\circ} \mathrm{C}$ with $5 \% \mathrm{CO}_{2}$ and $95 \%$ air. Cell viability was determined by measuring the fluorescent signal at F530/620 nm (Excitation/Emission) on a Synergy 2 Microplate Reader (Bio-Rad, CA, USA). The obtained fluorescence magnitudes were used to calculate cell viability expressed as a percent of the viability of the untreated control cells.

To investigate the effect of the preparations on cell migration, cells were seeded into 96-well plates containing cell seeding stoppers (ORIS ${ }^{\mathrm{TM}}$ method) at a ratio of $4 \cdot 10^{4}$ per well for HeLa cells and $5 \cdot 10^{4}$ per well for MCF-7 cells in complete medium. After $24 \mathrm{~h}$ of incubation the stoppers were removed and cells were incubated in serum free medium in the presence of the extract diluted in DMSO and cultured medium for $24 \mathrm{~h}$. Closure of the cell-free space was measured and recorded with a Leica M205C microscope (MDG4 model) using the Leica program, both immediately and at $24 \mathrm{~h}$ and $48 \mathrm{~h}$ after removing the stoppers, and then compared to the initial 
cell-free space size at $0 \mathrm{~h}$. The extent of migration was defined as the ratio of the difference between the original and the remaining wound areas compared with the original wound area. As a positive control, $10 \%$ FBS was used.

The mitochondrial membrane potential was assayed with a JC-1 probe. After treatments with the studied compounds, the medium was changed and JC-1 $(1 \mu \mathrm{g} / \mathrm{mL})$ was added for $20 \mathrm{~min}$. Then, the cells were washed with serum-free medium and the fluorescent signal was measured at F530/620 nm, F485/528 nm, 485/620 nm. As a positive control, the known mitochondrial uncoupler CCCP (carbonyl cyanide 3-chlorophenylhydrazone) was used at a concentration of $50 \mu \mathrm{M}$. To determine the effect of the Viburnum opulus extracts on the intracellular generation of ROS, the DCFH-DA assay was performed. After incubating the cells for $20 \mathrm{~h}$ with extracts, they were washed with PBS and loaded with the DCFH-DA dye at a final concentration of $1 \mu \mathrm{M}$ in serum-free medium for $40 \mathrm{~min}$. The cells were then washed twice with PBS and the fluorescent signal at F485/528 $\mathrm{nm}$ was measured.

\section{Results and discussion}

There are few reports on Viburnum opulus composition and even fewer on its biological activity. However, it is known that guelder rose fruits contain large amounts of polyphenolic compounds corresponding to $65 \mathrm{mg}$ of polyphenols per $1 \mathrm{~g}$ of fruit $[6,7]$. Gallic acid was identified as the main polyphenolic compound in an amount of $8.29 \mathrm{~g} / \mathrm{kg}$ fresh weight. Further compounds identified were chlorogenic acid, catechin, epicatechin, rutin, quercetin flavonoids, procyanidin B2, procyanidin trimer and proanthocyanidin dimer monoglycoside [8]. While discussing the results of the research we suggest the presence of the mentioned phytochemicals in the obtained preparations. Ulger et al. reported that the total number of tumor lesions were reduced in mice with colon cancer when treated with 1,2-dimethylhydrazine drinking water enriched with guelder juice at the initiation stage of tumorgenesis [9]. In this report we demonstrated that polyphenolic extracts of Viburnum opulus fruit exhibit anticancer activity with simultaneous decrease of cell metabolic activity and antioxidant properties.

PrestoBlue assay was used to assess the cytotoxicity of the preparations. Firstly, we determined the concentrations able to inhibit the viability of HeLa and MCF-7 cells at $50 \%$ compared to controls as well as the highest non-toxic concentrations. The obtained $\mathrm{IC}_{50}$ and $\mathrm{IC}_{0}$ parameters are listed in Tab. 1 . Fig. 1 demonstrates the influence of preparations on cellular viability. The highest cytotoxic activities against both cell lines were observed for the preparation obtained by extraction of solid phase (PF) from centrifuged juice. The $I_{50}$ parameters values are $63.541 \mu \mathrm{g} / \mathrm{mL}$ and $96.909 \mu \mathrm{g} / \mathrm{mL}$ for the HeLa and MCF-7 cells, respectively. In turn, the results indicate the lowest cytotoxicity of juice in both studied biological models. The lowest influence of a $50 \%$ decrease of cell viability was observed for centrifuged juice. The dependencies for both formulations seem to be justified. During the extraction to the solid phase we isolated certain flavonoid fractions, as well as flavonoid aglycons. We obtained a preparation free from proteins, polysaccharides and nucleic acids, which was chemically cleaner than the centrifuged juice [10]. For the other preparations ( $M$ and $A$ ), higher $I C_{50}$ parameter values were observed, in comparison to the PF preparation, however they were lower than for the juice. This means that the most bioactive compounds affecting the viability of cells are found in the solid phase extracted preparation. The methanolic and acetone extracts were extruded from the pomace and contained higher amount of polyphenolic compounds than the centrifuged juice. Using an MTT assay, Waheed et al. showed that almost twice the dose $(200 \mu \mathrm{g} / \mathrm{mL})$ of methanolic extract of Viburnum foetens inhibited the metabolic activity of Caco- 2 cells by $50 \%$. Significantly lower inhibition (about $20 \%$ ) with the same dose was obtained by Waheed against the MDA MB-468 cell line. In the presented studies all preparations showed higher toxicity to the cervical cancer cell line (HeLa) [11]. 


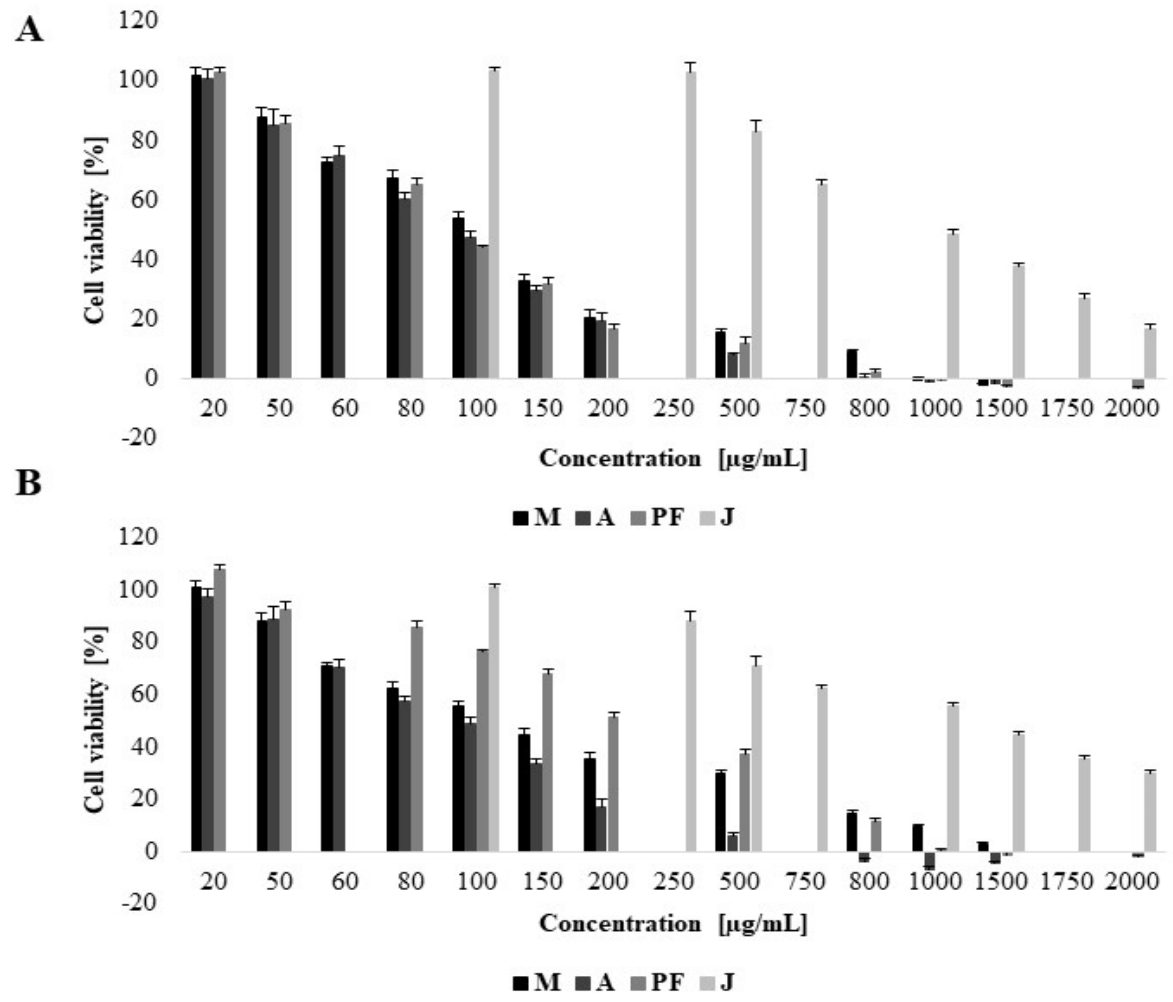

Fig. 1. Effect of Viburnum opulus fruit preparations on the viability of HeLa cells (A) and MCF cells (B) after $24 \mathrm{~h}$ incubation; values are mean \pm standard deviation from at least eight independent experiments; the abbreviations used indicate the type of preparation $\mathrm{M}$ - methanol; A - acetone; PF - polyphenolic fraction; J - juice.

Source: Author's

Table 1. $I C_{50}$ and IC $C_{0}$ parameters of extracts obtained for HeLa and MCF-7 cells; values are means \pm standard deviations from at least three independent experiments

\begin{tabular}{|c|c|c|c|c|}
\hline \multirow{2}{*}{ Preparations } & \multicolumn{2}{|c|}{ HeLa } & \multicolumn{2}{c|}{ MCF-7 } \\
\cline { 2 - 5 } & $\mathrm{IC}_{50}$ & $\mathrm{IC}_{0}$ & $\mathrm{IC}_{50}$ & $\begin{array}{c}\mathrm{IC}_{0} \\
(\mu \mathrm{g} / \mathrm{mL})\end{array}$ \\
$(\mu \mathrm{g} / \mathrm{mL})$ & $(\mu \mathrm{g} / \mathrm{mL})$ & $(\mu \mathrm{g} / \mathrm{mL})$ \\
\hline Methanol: & 100,867 & 20,173 & 121,466 & 24,293 \\
acetone: & $\pm 0,101$ & $\pm 0,078$ & $\pm 0,121$ & $\pm 0,487$ \\
water & & & & \\
\hline 70\% acetone & 100,046 & 20,009 & 243,641 & 48,728 \\
& $\pm 0,1$ & $\pm 0,128$ & $\pm 0,247$ & $\pm 0,307$ \\
\hline Polyphenol & 63,541 & 12,781 & 96,909 & 19,380 \\
fraction & $\pm 0,162$ & $\pm 0,43$ & $\pm 0,097$ & $\pm 0,154$ \\
\hline Juice & 1031,512 & 206,302 & 1134,535 & 226,907 \\
& $\pm 0,024$ & $\pm 0,362$ & $\pm 1,135$ & $\pm 0,783$ \\
\hline
\end{tabular}

Source: Author's

The yield of inhibition of migration of the cells pre-treated with Viburnum opulus changed over time, which means that polyphenolic compounds contained in the preparations had a short-term effect. On the second day the number of actively migrating cells increased unambiguously, however the observed effect was stronger in HeLa cells (Fig. 2-3). 


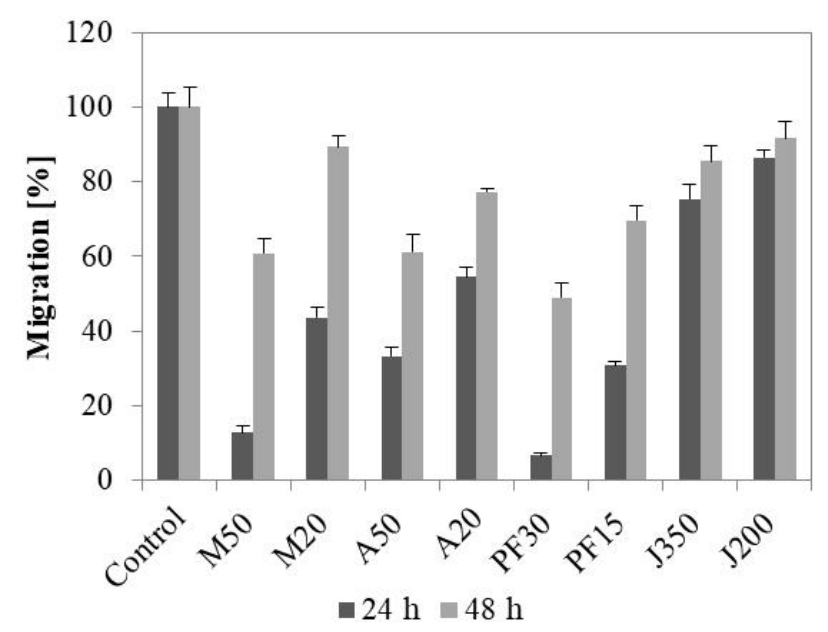

Fig. 2. Effect of Viburnum opulus fruit preparations on the rate of migration of the cervical cancer cell line (HeLa) for two incubation times ( $24 \mathrm{~h}$ and $48 \mathrm{~h}$ ); values are means \pm standard deviations from at least seven independent experiments; the abbreviations used indicate the type of preparation and the concentration used (for example M50 - methanol extract at concentration of $50 \mu \mathrm{g} / \mathrm{mL}$ )

Source: Author's
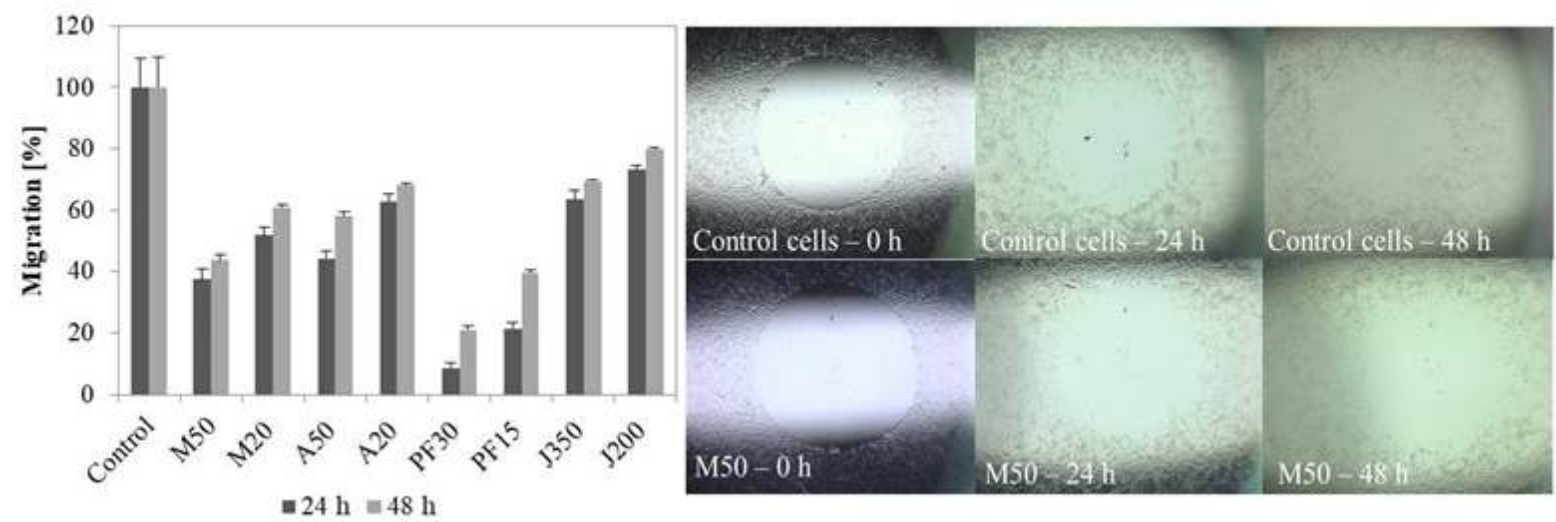

Fig. 3. Effect of Viburnum opulus fruit preparations on the rate of migration of the breast cancer cell line (MCF-7) for two incubation times ( $24 \mathrm{~h}$ and $48 \mathrm{~h}$ ) and observed wound area of representative experiment; values are means \pm standard deviations from at least seven independent experiments; the abbreviations used indicate the type of preparation and the concentration used (for example, M50 - methanol extract at concentration of $50 \mu \mathrm{g} / \mathrm{mL}$ )

Source: Author's

The anti-cancer properties of Viburnum opulus preparations are supported by a high content of polyphenolic compounds, like quercetin, epigallocatechin gallate (EGCG) and orgallic acid [13]. To the best of our knowledge there are no reports on the influence of extracts rich in polyphenolic compounds on the migration of tumor cells, but only reports of individual phytochemicals. Yu et al. analyzed the effect of quercetin $(20 \mu \mathrm{M}, 40 \mu \mathrm{M}, 80$ $\mu \mathrm{M}$ ) on the migration of pancreatic cancer cells using the scratch test and the Transwell chamber. In all cases, after $24 \mathrm{~h}$ incubation the obtained results showed a correlation between the increase in the concentration of quercetin and a decrease in the number of cells that actively migrated. The inhibition of the rate of overgrowth observed was associated with the inhibition of migration, but also with a cytotoxic effect caused by quercetin [14]. In 2017, Farabegoli reported an inhibiting effect of EGCG at $25 \mu \mathrm{g} / \mathrm{mL}$ on MFC-7 cells migration based on the scratch assay. The concentration used did not demonstrate cytotoxicity to MCF-7 cells, but migration was inhibited by about $35 \%$ in comparison to cells cultured without polyphenols. After 48 hours the migration level was $37 \%$ lower. The effect of reduction of level of migration persisted for 72 hours and reached $45 \%$. The study suggests that MFC-7 cells are susceptible to EGCG in the context of suppression of the migration process. This is also the basis for confirming the correctness of the results obtained in this work [15]. Another research study proved that polyphenol extract from Phyllanthus emblica (PEEP) tan grass leaves obtained by extraction with $70 \%$ acetone, inhibited proliferation of HeLa cells by $39 \%$ at a dose of PEEP $150 \mathrm{mg} / \mathrm{mL}$ [16]. The results of our work indicate that the preparation made with the same extraction method inhibits the migration of HeLa cells by about $85 \%$ the first day and by $40 \%$ on the second day at a non-toxic $50 \mu \mathrm{g} / \mathrm{mL}$ concentration. 
The reduction of tumor invasiveness by lowering the rate of cell migration may have a different molecular basis. In counteracting tumor growth, modern medicine is based on reduction of the activity of small GTPases from the Rho protein family, metalloproteinases (MMP), vascular endothelial growth factor (VEGF), as well as the reduced expression of focal adhesion kinase (FAK) and c-Jun N-terminal kinases (JNK) [17, 18]. The debilitating factor of tumor cell invasiveness is mitochondrial dysfunction, which is accompanied by decrease of the mitochondrial potential, and in consequence, apoptotic cell death. Depolarization of mitochondrial membrane is caused by excessive production of reactive oxygen species (ROS), fragmentation of mitochondrial DNA (mtDNA), protein cross-linking and peroxidation of membrane phospholipids [19].

Mitochondrial dysfunction can promote progression of a cancer to an apoptosis-resistant/chemo-resistant and/or invasive phenotype by various mechanisms. During oncogenesis and tumor progression these mitochondrial alterations can activate cytosolic signaling pathways from mitochondria to the nucleus and ultimately alter nuclear gene expression for neoplastic transformation [20]. Chen et al. reported that caffeic acid phenethyl ester (CAPE), an active component isolated from honeybee propolis, induced apoptosis in human pancreatic cancer cells at $10 \mu \mathrm{g} / \mathrm{mL}$, significantly decreased transmembrane potential of the mitochondrion in BxPC-3 cells and induced morphological changes of typical apoptosis (a 2-fold increase in caspase-3/caspase-7 activity in comparison to control cells) [21].

These reports have led us to attempt to determine the effect of Viburnum opulus on the mitochondrial potential and to link this phenomenon with a reduction in the rate of migration of tumor cell lines HeLa and MCF-7. For this purpose, we performed a test using a cationic dye $\left(5,5^{\prime}, 6,6^{\prime}\right.$-tetrachloro-1,1',3,3'tetraethylbenzimidazolylcarocyanine iodide), which signals the mitochondrial membrane potential decrease. In healthy cells, the negative charge of the membrane allows the cationic dye to pass into the mitochondrial matrix where it accumulates into red aggregates with fluorescence when measured at 530/620 nm (it is excited by green light). In apoptotic cells, the mitochondrial potential decreases and the charge of the vines change, so that the cationic dye cannot accumulate in the mitochondria and accumulates in the cytoplasm in a monomeric form emitting green fluorescence, which is measured at $485 / 528 \mathrm{~nm}$ when excited by blue light. The ratio of red to green fluorescence is defined as the health of cells. The wavelength of $485 / 620 \mathrm{~nm}$ is used to measure fluorescence, which presents the degree of polarity of the mitochondrial membrane [22].

The results of the JC-1 test are shown for the HeLa cervical cancer cell line (Fig. 4) and for the human breast cancer cell line (Fig. 5). For both lines, at each concentration of preparations, a decrease of mitochondrial potential, as well as a decrease in metabolic activity, were noticed. These results were closely correlated with the applied concentration of formulations as well as the degree of migration of HeLa and MCF-7 cells. Again, the most active was a highly purified PF preparation. The preparations reduced the polarity of the mitochondrial membrane by nearly $50 \%$ at a non-toxic $\mathrm{IC}_{0}$ concentration, and at a concentration of $30 \mu \mathrm{g} / \mathrm{mL}$ by nearly $60 \%$, which was comparable to the CCCP used as positive control. It is worth noting that all tested preparations showed a higher ability to induce a decrease in potential and metabolic activity in the MCF-7 breast cancer line, which could also be noted in the long-term inhibition of the proliferation rate of these cells. An equally high depletion of mitochondrial potential was observed for centrifuged juice, however it worked more strongly against the MCF-7 than HeLaline. Significant differences in the effects on the two cell lines were observed for the $\mathrm{M}$ and $\mathrm{A}$ formulations. This time, the methanol: acetone: water $(\mathrm{v} / \mathrm{v} / \mathrm{v})$ preparation was more active against the HeLa line than the MCF-7. However, the preparation extracted with $70 \%$ acetone reduced the mitochondrial potential and metabolic activity to the same extent for both cell lines. 


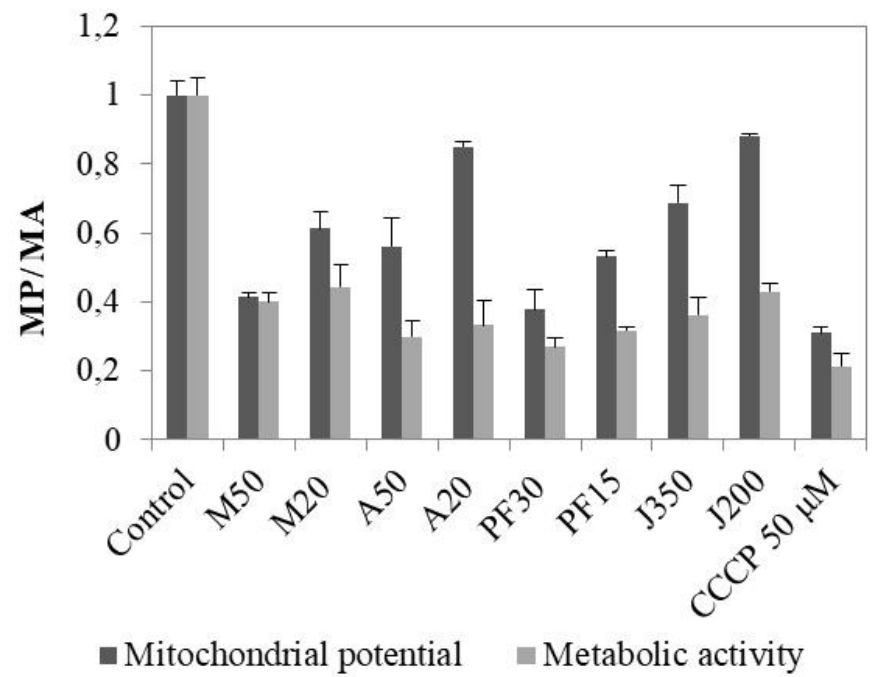

Fig. 4. Effect of Viburnum opulus fruit preparations on mitochondrial potential (MP) and metabolic activity (MA) of cervical carcinoma cell lines (HeLa); values are means \pm standard deviations from at least three independent experiments; the abbreviations used indicate the type of preparation and the adjusted concentration (for example M50 - methanol extract in a concentration of $50 \mu \mathrm{g} / \mathrm{mL}$ )

Source: Author's

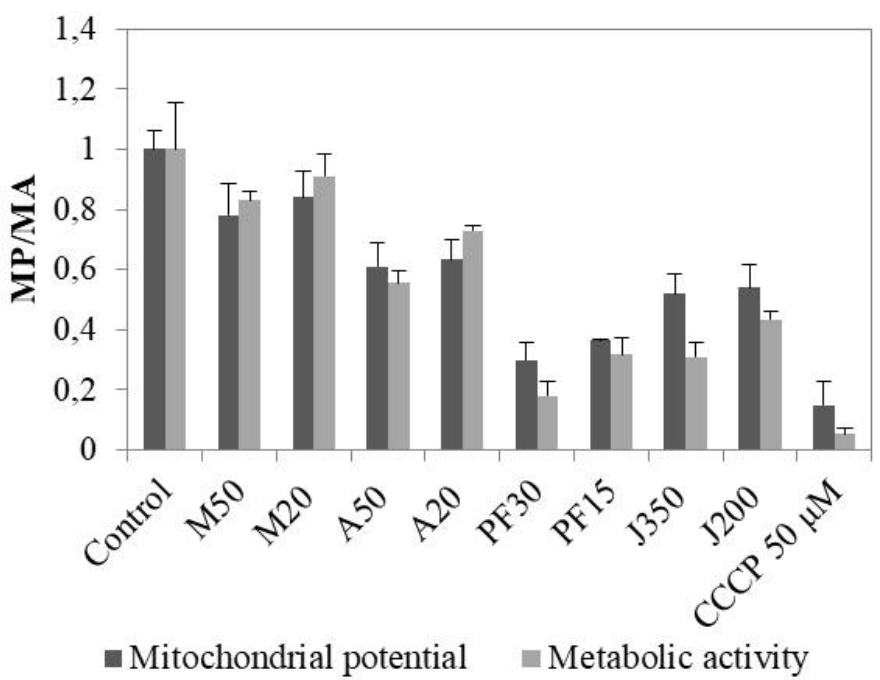

Fig. 5. Effect of Viburnum opulus fruit preparations on mitochondrial potential (MP) and metabolic activity (MA) of breast cancer cell lines (MCF-7); values are means \pm standard deviations from at least three independent experiments; the abbreviations used indicate the type of preparation and the concentration used (for example, M50 - methanol extract at a concentration of $50 \mu \mathrm{g} / \mathrm{mL}$ ) Source: Author's

Drastic reduction of mitochondrial potential with simultaneous loss of cell biological activity usually lead to cellular apoptosis. Resistance to apoptosis is the main cause of cancer's insensitivity to conventional therapies. Therefore, one of the strategies employed is to look for factors that lead to cellular apoptosis induction. The latest reports showed that caffeic acid phenethyl ester (CAPE), a functional ingredient isolated from propolis, effectively reduced the number of proinflammatory cytokines and inflammatory mediators by inhibiting the transcription of the nuclear factor $\mathrm{k}$-light chain inhibitor of activated B cells (NF-KB). Several papers focused on the protective role of CAPE against general tumor models, both in vivo and in vitro for melanomas, lung and prostate cancers [23]. CAPE is a natural phenolic compound and an ester of phenethyl alcohol in the form of caffeic acid. Its presence was also found in the fruit of Viburnum opulus [8]. These reports lead us to conclude that the Viburnum opulus preparations we examined are capable of inducing mitochondrial dysfunction. This was proven by the reduction of the mitochondrial potential and the decrease in the metabolic activity of cancer cells. This resulted in the activation of caspase-3 and caspase-7, inhibition of the NF-kB factor, activation of the 
Fas signal and ultimately in apoptosis induction. Analogous results for MCF-7 breast cancer were obtained by Liao et al., which were simultaneously proven in many independent studies with other cell lines [24].

The reduction of mitochondrial potential and dysfunction is accompanied by damage to the respiratory chain and overproduction of reactive oxygen species (ROS). This is observed due to the increased number of reduced forms of electron and proton transporters, such as the reduced form of nicotinamide adenine dinucleotide $(\mathrm{NADH}+\mathrm{H}+$ ) and flavin adenine dinucleotide $(\mathrm{FADH} 2)$. The consequence of this process is the hyperpolarization of the internal mitochondrial membrane by increased electron flow through the respiratory chain. Finally, it stops the transformation of the respiratory chain at the complex III and the increased production of superoxide anion horn and mitochondrial dysfunction [25]. Taking this into consideration, we performed a study of the preparations influence on the intracellular oxidative stress using the DCFH-DA probe. This method consists of oxidizing the substrate $\left(2^{\prime}, 7^{\prime}\right.$-dichlorodihydrofluorescein) introduced into the system in the form of an ester (diacetate, H2DCF-DA). The ester undergoes spontaneous hydrolysis reaction or a hydrolysis reaction which is catalyzed by hydrolases with the release of the product in the form of an oxidized DCF-DA, which can be recorded.

The results indicated the antioxidant capacity of the studied preparations of Viburnum opulus (Fig. 6). The highest decrease in ROS was observed for the PF preparation, as well as for the juice. At the $\mathrm{IC}_{20}$ concentration of $\mathrm{PF}$, intracellular oxidative stress was reduced by $40 \%$ for HeLa and by $20 \%$ for MCF-7 cells. M and A formulations at $\mathrm{IC}_{0}$ and $\mathrm{IC}_{20}$ resulted in the reduction of ROS concentrations by approximately $20 \%$. It is clear that polyphenols contained in plant extracts have the ability to inhibit the production of free radicals, however, during mitochondrial dysfunction the apoptosis-induced ROS concentration in cells increase [18]. In 2016, Li et al. demonstrated that green tea preparation influenced internal oxidative stress of MCF-7 cells with an approximately 11-fold increase in ROS accumulation at $50 \mathrm{mg} / \mathrm{mL}$ dosage of preparation. Payen et al. showed that in SiHa-F3 cells EGCG at concentrations of $100 \mathrm{nM}, 1 \mu \mathrm{M}, 10 \mu \mathrm{M}$ and $100 \mu \mathrm{M}$ revealed a growing antioxidant effect which was correlated with the EGCG concentration [26].

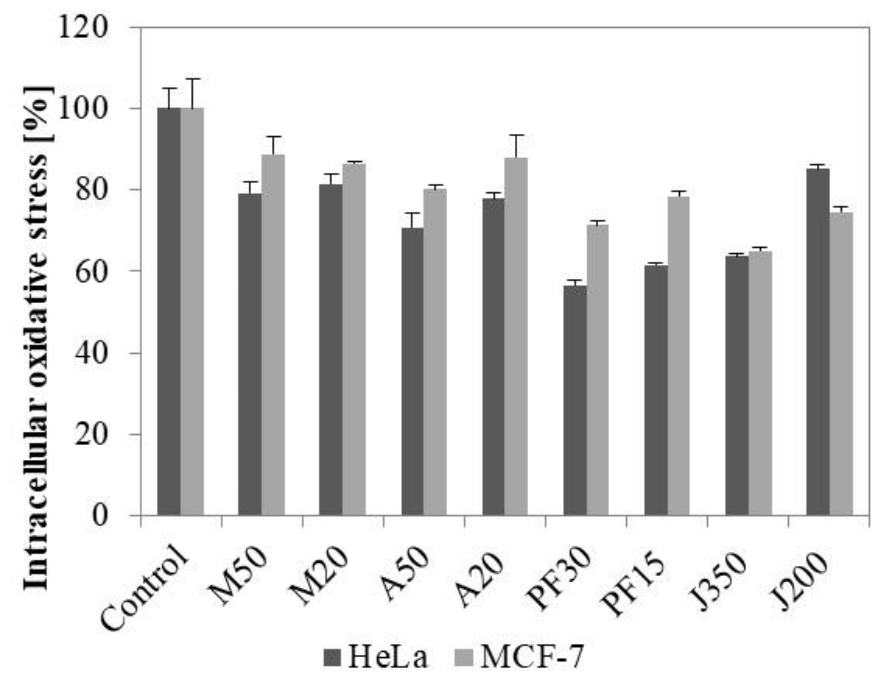

Fig. 6. Effect of Viburnum opulus fruit preparations on intracellular oxidative stress of cervical carcinoma cell line (HeLa) and breast cancer cell line (MCF-7); values are means \pm standard deviations from at least three independent experiments the abbreviations used indicate the type of preparation and the concentration used (for example, M50 - methanol extract at a concentration of $50 \mu \mathrm{g} / \mathrm{mL}$ )

Source: Author's

\section{Summary and conclusions}

In summary, there is great interest in polyphenolic compounds in the context of antitumor activity, as well as in their inhibition of tumor cell migration and metastasis. In recent years a number of studies have been carried out showing a relationship between the increase of the concentration of various polyphenolic compounds (such as caffeic acid, gallic acid, quercetin, epigallocatechin gallate) and a decrease of migration process. The conducted studies showed that polyphenolic preparations obtained from Viburnum opulus fruits inhibit the migration of tumor cells. In some cases there is a drastic reduction in the number of migrating cells (up to 90\% 
- PF in the concentration of $30 \mu \mathrm{g} / \mathrm{mL}$ ) for both of cell lines. At the same time, they show the ability to reduce the mitochondrial potential and metabolic activity of cells (up to $80 \%$ for PF for MCF cells), which was probably correlated with the degree of reduction of actively migrating cells. Despite the ability to drastically decrease the polarization of the mitochondrial membrane, the tested extracts showed antioxidant properties, which seem to also have a beneficial effect. The results obtained indicate the high potential of Viburnum opulus polyphenolic compounds as components that can be used in the production of innovative dietary supplements or pharmacological preparations dedicated to people with increased risk or inclination of breast or cervical cancer.

\section{Acknowledgements}

This research was financially supported in part by grant from National Science Centre (No. 2016/23/B/N29/03629).

\section{References}

[1] A. Jemal, R. Siegal, E. Ward, Y. Hao, J. Xu, T. Murray, M.J. Thun, Cancer statistics, A Cancer Journal for Clinicians. 58 (2008) 71-96.

[2] D. Ceylan, A. Aksoy, T. Ertekin, A.H. Yay, M. Nisari, S.G. Karatoprak, H. Ülger, The effects of gilaburu (Viburnum opulus) juice on experimentally induced Ehrlich ascites tumor in mice, Journal of Cancer Research and Therapeutics. 14 (2018) 314-320.

[3] M. Çam, Y. Hişil, Comparison of chemical characteristics of fresh and pasteurised juice of gilaburu (Viburnum opulus L.), Acta Aliment. 36 (2007) 381-385.

[4] M.V. Gavrilin, M. Markova, T. Likhota, A. Izmailova, Optimization of the procedure of vitamin determination in Viburnum oil, Pharmaceutical Chemistry Journal. 41 (2007) 101-104.

[5] K.D. Miller, R.L. Siegel, C.C. Lin, A.B. Mariotto, J.L. Kramer, J.H. Rowland, K.D. Stein, R. Alteri, A. Jemal, Cancer treatment and surivorship statistics, A Cancer Journal for Clinicians. 66 (2016) 271-289.

[6] M. Zakłos-Szyda, I. Majewska, M. Redzynia, M. Koziołkiewicz, Antidiabetic Effect of Polyphenolic Extracts from Selected Edible Plants as $\alpha$-Amylase, $\alpha$-Glucosidase and PTP1B Inhibitors, and $\beta$ Pancreatic Cells Cytoprotective Agents - A Comparative Study, Current Topics in Medicinal Chemistry. 15 (2015) 2431-2444.

[7] O. Rop, V. Recnicek, M. Valsikova, T. Jurikova, J. Milcek, D. Kramarova, Antioxidant Properties of European Cranberrybush Fruit (Viburnum opulus var. edule), Molecules. 15 (2010) 4467-4477.

[8] H. Singh, M.K. Lily, K. Dangwal, Viburnum mullaha D. DON fruit (Indian cranberry): A potential source of polyphenol with rich antioxidant, anti-elastase, anti-collagenase, and anti-tyrosinase activities, International Journal of Food Properties. 20 (2017) 1729-1739.

[9] H. Ulger, T. Ertekin, O. Karaca, O. Canoz, M. Nisari, E. Unur, F. Elmal, Influence of gilaburu (Viburnum opulus) juice on 1,2-dimethylhydrazine (DMH)-induced colon cancer, Toxicology and Industrial Health. 29 (2013) 824-829.

[10] M. Machowski, D. Kaliszewska, A. Kiss, Chromatograficzne metody izolacji i identyfikacji flawonoidów i saponin (Chromatographic methods of isolation and identification of flavonoids and saponin), Biuletyn Wydziału Farmaceutycznego Warszawskiego Uniwersytetu Medycznego. 4 (2010) 27-37.

[11] A. Waheed, Y. Bibi, S. Nisa, F.M. Chaudhary, S. Sahreen, M. Zia, Inhibition of human breast and colorectal cancer cells by Viburnum foetensL. extracts in vitro, Asian Pacific Journal of Tropical Disease. 3 (2013) 32-36.

[12] Ch. Decaestecker, O. Debeir, P Van Ham, R. Kiss, Can Anti-Migratory Drugs Be Screened In Vitro? A Review of 2D and 3D Assays for the Quantitative Analysis of Cell Migration, Medicinal Research Reviews. 27 (2007) 149-176. 
[13] A. Konarska, M. Domaciuk, Differences in the fruit structure and the location and content of bioactive substances in Viburnum opulus and Viburnum lantana fruits, Springer Open Choice. 255 (2018) 23-41.

[14] D. Yu, T. Ye, Y. Xiang, Z. Shi, J. Zhang, B. Lou, F. Zhang, B. Chen, M. Zhou, Quercetin inhibits epithelialmesenchymal transition, decreases invasiveness and metastasis, and reverses IL-6 induced epithelialmesenchymal transition, expression of MMP by inhibiting STAT3 signaling in pancreatic cancer cells, OncoTargets and Therapy. 10 (2017) 4719-4729.

[15] F. Farabegoli, M. Govoni, A. Papi, EGFR inhibition by (-)-epigallocatechin-3-gallate and IIF treatments reduces breast cancer cell invasion, Bioscience Reports. 37 (2017) 170-178.

[16] X. Zhu, J. Wang, Y. Ou, W. Han, H. Li, Polyphenol extract of Phyllanthusemblica (PEEP) induces inhibition of cell proliferation and triggers apoptosis in cervical cancer cells, European Journal of Medical Research. 18 (2013) 46.

[17] C. Bonnas, J. Chou, Z. Werb, Remodelling the extracellular matrix in development and disease, Nature Reviews Molecular Cell Biology. 15 (2014) 786-801.

[18] T.Y. Forbes-Hernández, F. Giampieri, M. Gasparrini, L. Mazzoni, J.L. Quiles, J.M. Alvarez-Suarez, M. Battino, The effects of bioactive compounds from plant foods on mitochondrial function: $A$ focus on apoptotic mechanisms, Food and Chemical Toxicology. 68 (2014) 154-182.

[19] G.L. Nicolson, Mitochondrial Dysfunction and Chronic Disease: Treatment With Natural Supplements, Integrative Medicine. 13 (2014) 35-43.

[20] C.C Hsu, L.M. Tseng, H.C. Lee, Role of mitochondrial dysfunction in cancer progression, Experimental Biology and Medicine. 241 (2016) 1281-1295.

[21] M.J., Chen, W.H. Chang, C.Y. Liu, T.E. Wang, C.H. Chu, S.C. Shih, Y.J. Chen, Caffeic acid phenethyl ester induces apoptosis of human pancreatic cancer cells involving caspase and mitochondrial dysfunction, Pancreatology. 8 (2008) 566-576.

[22] D.L. Garner, C.A. Thomas, Organelle-specific probe JC-1 identifies membrane potential differences in the mitochondrial function of bovine sperm, Molecular Reproduction and Development. 53 (1999) 222-229.

[23] H.K Erdemli, S. Akyol, F. Armutcu, M.A. Gulec, M. Canbal, O. Akyol, Melatonin and caffeic acid phenethyl ester in the regulation of mitochondrial function and apoptosis: The basis for future medical approaches. Life Sciences. 148 (2016) 305-312.

[24] H.F. Liao, Y.Y. Chen, J.J. Liu, M.L. Hsu, H.J. Shieh, H.J. Liao, C.J. Shieh, M.S. Shiao, Y.J. Chen, Inhibitory Effect of Caffeic Acid Phenethyl Ester on Angiogenesis, Tumor Invasion, and Metastasis, Journal of Agricultural and Food Chemistry. 51 (2003) 7907-7912.

[25] K. Siewiera, M. Łabieniec-Watała, Rola polifenoli roślinnych w łagodzeniu niekorzystnego wpływu cukrzycy na homeostazę funkcjonowania mitochondriów (The role of plant polyphenols in alleviating the adverse effects of diabetes on mitochondrial homeostasis), Postępy Fitoterapii. 1 (2013) 36-41.

[26] W. Li, N. He, L. Tian, X. Shi, X. Yang, Inhibitory effects of polyphenol-enriched extract from Ziyang tea against human breast cancer MCF-7 cells through reactive oxygen species - dependent mitochondria molecular mechanism, Journal of Food and Drug Analysis. 2 (2015) 101-112. 